\title{
Justicia pectoralis Jacq., Acanthaceae: preparation and characterisation of the plant drug including chromatographic analysis by HPLC-PDA
}

\author{
Francisco N. Fonseca, Aline Holanda Silva, Luzia K. A. M. Leal
}

\begin{abstract}
${ }^{1}$ Programa de Pós-graduação em Ciências Farmacêuticas, Setor de Farmacognosia, Laboratório de Tecnologia de Produtos Naturais, Departamento de Farmácia, Faculdade de Farmácia, Odontologia e Enfermagem, Universidade Federal do Ceará, 60430-370 Fortaleza-CE, Brazil.
\end{abstract}

\begin{abstract}
RESUMO: Justicia pectoralis Jacq., Acanthaceae, é uma erva conhecida popularmente no Nordeste como chambá e, utilizada tradicionalmente no tratamento de doenças do trato respiratório, como a asma, tosse e bronquite. Essa espécie encontra-se na Relação Nacional de Plantas Medicinais de Interesse para o SUS. O objetivo do presente estudo foi elaborar protocolo para a preparação da droga vegetal a partir de $J$. pectoralis e realizar a sua caracterização visando seu emprego como matéria-prima farmacêutica. A parte aérea de $J$. pectoralis, após secagem em estufa com circulação e renovação de ar $\left(35^{\circ} \mathrm{C}\right)$ durante diferentes períodos de tempo (1-5 dias) mostrou a partir de $24 \mathrm{~h}$ de secagem um teor de umidade abaixo do valor máximo permitido para drogas vegetais. O pó da droga vegetal foi classificado como pó moderadamente grosso e, caracterizado quanto aos teores de cinzas totais, extrativos solúveis em água e etanol. Análise do extrato hidroalcoólico (etanol 20\%) de $J$. pectoralis por Cromatografia Líquida de Alta Eficiência (CLAE-DAD) determinou um teor de cumarina e umbeliferona de 16,2 e $0,81 \mathrm{mg} / \mathrm{g}$ da droga vegetal, respectivamente. As condições de preparação da droga vegetal e os parâmetros de controle de qualidade determinados para $J$. pectoralis no presente estudo são de interesse no desenvolvimento de fitoterápicos que empreguem esse matéria-prima ativa.
\end{abstract}

Unitermos: Justicia pectoralis, cumarina, umbeliferona, CLAE-DAD, controle de qualidade, matéria-prima vegetal.

\begin{abstract}
Justicia pectoralis Jacq., Acanthaceae, is a herb popularly known in Brazilian northeast as "chambá" and used in folk medicine for the treatment of respiratory tract conditions such as asthma, cough and bronchitis. This species is included in the National Register of Plants of Interest to the National Health System. The aim of the present study was to develop a protocol for the preparation of the plant drug from $J$. pectoralis and to characterise the plant drug for its use as a pharmaceutical raw material. The aerial parts of $J$. pectoralis, after drying chamber with forced air circulation $\left(35^{\circ} \mathrm{C}\right.$ ) for different periods of time (1-5 days), presented after one day a moisture content below the maximum allowed for plant drugs. The powder of the plant drug was classified as moderately coarse, and the total ashes content and the water- or ethanolsoluble extractives were determined. Analysis of hydroalcoholic (ethanol 20\%) extract of $J$. pectoralis by high performance liquid chromatography-photo diode array (HPLCPDA) determined the content of coumarin and umbelliferone $(16.2$ and $0.81 \mathrm{mg} / \mathrm{g}$ plant drug, respectively). The preparation conditions of the plant drug and the quality control parameters established for $J$. pectoralis in this study are of interest for the development of phytomedicines which use this active raw material.
\end{abstract}

Keywords: Justicia pectoralis, coumarin, umbelliferone, HPLC-PDA, quality control, plant raw material. 


\section{INTRODUCTION}

The quality of a phytomedicine is determined by the quality of the plant drug, the intermediate product and by the properties of the final product, taking into consideration the requirements of good practice in the manufacture of pharmaceutical products of plant origin (Kroll \& Cordes, 2006; WHO, 2005). The quality control of these products employs pharmacognostic methods, physico-chemical control and microbiological monitoring (Kroll \& Cordes, 2006; Gaedcke, 2004; WHO, 1998). In this context, various analytical methods have been employed in the analysis of chemical markers, including thin layer chromatography, high performance liquid chromatography (HPLC) and gas chromatography (Angelova et al., 2008).

In Brazilian northeast, in particular in the state of Ceará, researchers have been engaged in the systematic study of species belonging to the project 'Living Pharmacies' ('Farmácias Vivas'; Matos, 2000), including Justicia pectoralis, which is also found in the National Register of Plants of Interest to the National Health System (Ministério da Saúde, 2008). Two varieties of Justicia pectoralis have been described, stenophylla and pectoralis, found in Brazil and the Caribbean, respectively (Oliveira \& Andrade, 2000; Trueba et al., 2001). Justicia pectoralis Jacq. var. stenophylla Leonard, Acanthaceae, is a sub-erect herb cultivated in Brazilian northeast, popularly known as "chambá", "anador" and "trevo-cumaru". The aerial parts of "chambá" are used in the form of artisanal preparations or as a pharmaceutical formulation (syrup) indicated for the treatment of respiratory diseases, such as cough, bronchitis and asthma (Matos, 2000).

Phytochemical studies on $J$. pectoralis revealed the presence of various compounds including coumarin (1,2-benzopyrone - $\mathrm{CM})$, umbelliferone (7-hydroxycoumarin - UMB), ortho-methoxylated glycosylflavones and justicidin B (Leal et al., 2000; Joseph et al., 1988). The pre-clinical toxicological assessment of the hydroalcoholic extract of "chambá" showed that the plant possesses low toxicity. In addition, the extract and chemical constituents, $\mathrm{CM}$ and $\mathrm{UMB}$, obtained from the plant exhibits antioxidant, antiinflammatory, antinociceptive and muscle relaxant activities (Trueba et al., 2001; Lino et al., 1997; Leal et al., 2000), as well as central effects described more recently in rats (Venâncio, 2010; Pereira et al., 2009). Preliminary clinical assessment (Nobre et al., 2006) of the efficacy of the "chambá" syrup in the treatment of asthmatic patients with mild to moderate asthma, reported that after one week of treatment the patients presented reduced obstruction of the airways, with increases in forced expiratory volume, forced vital capacity and maximum expiratory flow.

Coumarin is a heterocyclic, aromatic, organic compound found in numerous plant species with pharmacological potential such as Amburana cearensis, Mikania glomerata and Hybanthus ipecacuanha (Leal et al., 2000; Rocha et al., 2008). Due to its capacity to potentiate the proteolytic activity of macrophages, CM has been indicated for the treatment of patients with lymphoedema (Clodius \& Piller, 1978), while coumarinic derivatives, such as UMB, possess numerous specific pharmacological properties including antiinflammatory (Vasconcelos et al., 2009), spasmolytic (Lino et al., 1997), hypoglycaemic and hypolipidemic activities (Ramesh \& Pugalendi, 2005). Thus, considering the pharmacological potential of "chambá" and the lack of specifications for the quality control of this plant raw material, which is a pre-requisite for the production and registration of phytomedicines (Anvisa, 2010), the objective of the present study was to prepare and characterise the plant drug obtained from the aerial parts of J. pectoralis, with the determination of quality control parameters, including determination of the levels of active principles /chemical markers, coumarin and umbelliferone, in the plant by HPLC.

\section{MATERIAL AND METHODS}

\section{Plant material}

Aerial parts of Justicia pectoralis Jacq. var. stenophylla, Acanthaceae, were collected from the Medicinal Plants Garden of the Phytotherapy Research Group, Health Secretariat of the State of Ceará, Brazil. Exsiccates (numbers 16071 and 16079) of the species were deposited in the Herbário Prisco Bezerra at the Universidade Federal do Ceará.

\section{Preparation of the plant drug}

The aerial parts of $J$. pectoralis were dried in a drying chamber with circulation and continuous renewal of air for $6,12,24,48,72,96$ and $120 \mathrm{~h}$ at a temperature of $35 \pm 5{ }^{\circ} \mathrm{C}$. After drying, the material obtained was processed in a silager.

\section{Determination of desiccation loss: method of drying on an infrared balance}

Samples of the plant drug $(3 \mathrm{~g})$ were heated $\left(105^{\circ} \mathrm{C}\right)$ on a balance coupled to a system for drying by infrared irradiation. This procedure was repeated three times with three distinct samples and the results obtained for percent loss of mass were expressed as the mean and coefficient of variation.

\section{Granulometric analysis by sieving}

The granulometric characterization of the powder obtained from the aerial parts of J. pectoralis $(100 \mathrm{~g})$ was 
carried out by using a shaker coupled with sieves (mesh sizes: $0.125 ; 0.18 ; 0.25 ; 0.35 ; 0.71$ and $0.20 \mathrm{~mm}$ ). After 20 min under shaking the fractions were removed and the weight recorded. The results were expressed as the percentage of fractions retained. This procedure was repeated three times with three distinct samples (F. Bras. IV, 1988). The mean size of the particles was determined by the arithmetic method (Allen et al., 2007). The results were expressed as the mean and the coefficient of variation.

\section{Determination of total ash content}

Exactly three grams of pulverized plant drug were transferred to a porcelain crucible, previously baked and weighed. The sample was incinerated in a muffle furnace at a temperature of $450{ }^{\circ} \mathrm{C}$. Following incineration and cooling of the material in a desiccator, total ash content was calculated as a function of dried plant drug (F. Bras. IV, 2000). This procedure was repeated three times with three distinct samples and the results are expressed as the mean and coefficient of variation.

\section{Determination of the water extractable content}

Four grams of the triturated plant drug were macerated in $100 \mathrm{~mL}$ of distilled water for $24 \mathrm{~h}$, with the material being stirred during the first $6 \mathrm{~h}$. The macerate was filtered and $25 \mathrm{~mL}$ were transferred to a previously weighed container; after drying in an oven $\left(105^{\circ} \mathrm{C}\right.$ for 6 h) the extractable content was determined as a function of the weight of plant material (WHO, 1998). This procedure was repeated three times with three distinct samples and the results are expressed as the mean and coefficient of variation.

\section{Determination of the ethanol extractable content}

A filter paper cartridge, previously weighed, was filled with $2 \mathrm{~g}$ of plant drug and subjected to extraction in a Soxhlet system. Potassium hydroxide $(200 \mathrm{mg})$ were added to the extraction solvent (ethanol) and the extraction was realized during for $5 \mathrm{~h}$. Next, the residue from the cartridge was dried in an oven at $105{ }^{\circ} \mathrm{C}$ for $30 \mathrm{~min}$. The extract content was calculated as a function of the weight of the plant drug (F. Bras. IV, 2000). This procedure was repeated three times with three distinct samples and the results are expressed as the mean and coefficient of variation.

Quantitative analysis of chemical markers in the hydroalcoholic extract of "chambá": coumarin and umbelliferone

The hydroalcoholic extract of "chambá" was produced according to a method described previously by Fonseca (2009), involving $2^{3}$ factorial planning with center points, where the influence of three variables (time of maceration, drug:solvent ratio and content of ethanol in water) on production of the extract was examined, employing as the outcome the concentration of CM and UMB determined by high performance liquid chromatography-photo diode array (HPLC-PDA). In the present study $100 \mathrm{~g}$ of pulverized plant drug were subjected to percolation after macerating for $24 \mathrm{~h}$ at room temperature. Following filtration $1500 \mathrm{~mL}$ of the extract were collected, with a solid residue content of $1.51 \pm 0.03 \%$ $(\mathrm{m} / \mathrm{v})$. The detection and simultaneous quantification of $\mathrm{CM}$ and $\mathrm{UMB}$ in the extract was achieved on an Alliance HPLC-PDA system (Waters, USA), employing a method validated previously (Fonseca et al., 2008; Fonseca, 2009), according to the criteria proposed by the National Agency for Sanitary Surveillance (Anvisa, 2003). To this end, aliquots of the extract were diluted 1:5 in the mobile phase and filtered through a $0.45 \mu \mathrm{m}$ filter unit (Millipore, USA). The analyses were performed under the following conditions: $\mathrm{C} 18$ column, mobile phase (A, AcN:MeOH:THF; $\mathrm{B}, \mathrm{H}_{2} \mathrm{PO}_{4}: \mathrm{Et}_{3} \mathrm{~N}, \mathrm{pH}$ 3), elution gradient, injection volume of $20 \mu \mathrm{L}$, flow rate $1.8 \mathrm{~mL} /$ min and $\lambda=323 \mathrm{~nm}$.

\section{Statistical analysis}

The data were analyzed with the aid of the program Graph Pad Prism 4.0 (USA). The results were expressed as mean \pm standard deviation and coefficient of variation. The means were compared using Student's $t$-test. Differences were considered statistically significant when $p<0.05$.

\section{RESULTS}

The fresh plant (moisture: $81.7 \pm 0.36 \%$ ), dried in an oven with circulation and renewal of the air within different periods ( 6 to $120 \mathrm{~h}$ ) revealed a moisture content that varied between 52.4 and $9.0 \%$, with this value remaining constant at $9.9 \%$ from $24 \mathrm{~h}$ onwards. Analysis of the plant drug produced at room temperature, in turn, revealed a moisture content of $16.7 \%$ after 5 days of drying (Table 1).

The plant drug was further characterized through chromatographic analysis, performed by HPLC-PDA, of the hydroethanolic extract produced from the plant drug prepared either in an oven (drying time: $24 \mathrm{~h}$ ) or at room temperature (Figure 2). The CM content $(16.19 \mathrm{mg} / \mathrm{g}$ of drug) of the extract produced from the plant drug prepared in an oven was significantly higher (around five times, $p<0.0001$; Student's $t$-test) than that of the plant drug prepared at room temperature $(2.39 \mathrm{mg} / \mathrm{g}$ of drug). On the other hand, the UMB content determined in the extracts mentioned did not differ significantly (Table 2). 
Table 1. Moisture content of the plant drug from Justicia pectoralis prepared in an oven with circulation and continuous renewal of air, determined at different time points.

\begin{tabular}{ccc}
\hline Method of drying & \multicolumn{3}{c}{ Moisture (\%) } \\
\hline Oven time (h) & $\mathrm{X}$ & $\mathrm{CV}(\%)$ \\
\hline 0 & 81 & 0,44 \\
6 & 52,9 & 1,18 \\
12 & 20,4 & 2,57 \\
24 & 9,9 & 10,7 \\
48 & 9,6 & 1,52 \\
72 & 9,5 & 3,35 \\
96 & 9,3 & 2,64 \\
120 & 9,0 & 1,37 \\
Room (120 h) & 16,7 & 3,08 \\
\hline
\end{tabular}

Plant material was dried at a temperature of $35 \pm 5{ }^{\circ} \mathrm{C}$. The analyses were carried out in triplicate. $\mathrm{X}$ : mean value and $\mathrm{CV}$ : coefficient of variation.

Trituration of the plant drug enabled the material to be reduced to particles of a small size, with a mean diameter of $0.590 \mathrm{~mm}$ (Table 2), characterized as a moderately course powder (WHO, 1998). Figure 1 shows the granulometric distribution of the plant drug, where most of the particles were retained by screens with a mesh opening of $0.71 \mathrm{~mm}$. The total ash content of the dried aerial parts of $J$. pectoralis was found to be $12.3 \%$, while the mean content of substances extractable in water was found to be lower than that of substances extractable in ethanol (Table 2).

Table 2. Physical and chemical analysis of the ground aerial parts of Justicia pectoralis.

\begin{tabular}{lcc}
\hline \multirow{2}{*}{ Parameters } & \multicolumn{2}{c}{ Plant drug } \\
\cline { 2 - 3 } & $\mathrm{X}$ & $\mathrm{CV}(\%)$ \\
\hline Mean diameter of particles & $0.590 \mathrm{~mm}$ & 2.54 \\
Total ashes & $12.3 \%$ & 1.36 \\
Contents extractable in water & $0.2 \%$ & 4.08 \\
Contents extractable in ethanol & $12.8 \%$ & 4.94 \\
Coumarin (mg/g) & & \\
Oven drying & $16.19 \mathrm{mg} / \mathrm{g} *$ & 2.49 \\
Room temperature drying & $2.39 \mathrm{mg} / \mathrm{g}$ & 3.01 \\
Umbelliferone (mg/g) & & \\
Oven drying & $0.81 \mathrm{mg} / \mathrm{g}$ & 4.49 \\
Room temperature drying & 0.78 & 5.59 \\
\hline
\end{tabular}

Plant material was dried at a temperature of $35 \pm 5^{\circ} \mathrm{C}$. The results represent the mean of three determinations. $\mathrm{X}$ : mean value; $\mathrm{CV}$ : coefficient of variation. ${ }^{*}=$ vs drying at room temperature $(p<0.05$, Student's t-test $)$

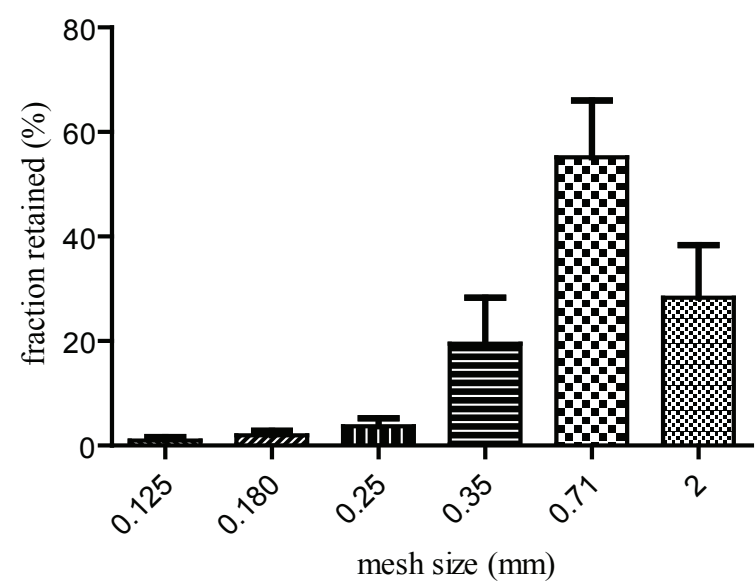

Figure 1. Granulometric distribution of particles of the ground, dried aerial parts of $J$. pectoralis. Screens with mesh sizes of 2.0-0.125 $\mathrm{mm}$ were employed. The results obtained from three separate determinations were expressed as the mean \pm standard deviation.

\section{DISCUSSION}

The present work investigated the protocol for preparation, specifically the drying time, of the plant drug of $J$. pectoralis; the latter was also characterized with a view to its use as pharmaceutical raw material.

A plant drug corresponds to a medicinal plant, or its parts, containing the substances, or classes of substances, responsible for a therapeutic effect, following the processes of collection, stabilization, when necessary, and drying; the material may be in its whole form, scored, triturated or pulverized (Anvisa, 2010). When considering plant drugs, the moisture content is a parameter that can interfere considerably in the stability of the active constituents present in the plant, since excessive water in the plant raw material favours the action of enzymes whose activity may lead to the degradation of chemical constituents, as well as enabling the development of fungi and bacteria. Toxigenic fungi, such as those of the Aspergillus genus, are xerophilic, which means that they develop even in conditions of low humidity. For this reason the maximum moisture content established in several pharmacopoeias, including the Brazilian, is in the range 8-14\%, with few exceptions given in monographs (Farias, 2007; Yamamoto et al., 2004). In the present work drying the plant in an oven for at least $24 \mathrm{~h}$ resulted in the raw material having a moisture content below the maximum recommended limit of $8-14 \%$ (F. Bras. IV, 2000).

In the analysis of the plant drug prepared at room temperature, performed since it is one of the methods most widely employed by Public Phytotherapy Programmes in Brazilian northeast, we observed that the mean moisture content was above $14 \%$. In addition, the plant drug presented a distinct colour (dark green - black) when related to that produced in the oven. While drying at room 
temperature took place in a room with a dehumidifier, it is possible that even under these conditions the atmosphere could be saturated with water vapour, so that it could favour the occurrence of fermentative processes in the plant with consequent changes in its organoleptic characteristics.

The size of the particles of a pulverized plant drug directly influences the efficiency of an extraction process; for example, methods that involve filtration of a very fine powder (particle size below $0.125 \mathrm{~mm}$ ) can compromise the extraction (Prista et al., 1996, Sharapin, 2000; List \& Schmidt, 2000). In this context, the moderately coarse powder of "chambá" is advantageous, and the use of powders of this nature is recommended for the majority of plant drugs (Sharapin, 2000).

The measurement of ashes is intended to establish the quantity of non-volatile inorganic impurities. The ash content comprises both the physiological ashes, derived from the plant tissues, as well as non-physiological ashes (F. Bras. IV, 2000; WHO, 1998). Elevated ash contents in aerial material of interest (leaves, inflorescences and flowers) may indicate external material adhered to the surface of the plant, such as sand and silica. In the present work, both the total ashes content and the content of extractable in water or ethanol determined were lower, in relation to the values reported by Govín et al. (2003) for the aerial parts of $J$. pectoralis var. pectoralis, cultivated in Cuba. These differences are possibly related to intrinsic variations among the varieties ( $J$. stenophylla and $J$. pectoralis), as well as differences in the metabolism of the plant, which is subject to change according to the habitat, the pattern of rainfall, sunlight, and soil, in other words the climatic-edaphic conditions (Evans, 1996; Blank et al., 2007).

Various chromatographic methods, including high performance liquid chromatography with a photo diode array detector (HPLC-PDA), have been used to separate, identify and quantify chemical markers in plant extracts, which in general have a complex chemical composition, besides the presence of interfering compounds (Wang \& Yang, 2007). A previous study (Leal et al., 2000) carried out in our laboratory determined the preliminary phytochemical profile of "chambá", detecting the presence of coumarin among other constituents of the plant. In the present study, analysis of the extract of "chambá" by HPLC-PDA enabled the separation and quantification of the coumarins (1,2-benzopyrone and 7-hydroxycoumarin) present in the plant and showed that the extract produced from the plant drug prepared in an oven possessed a higher concentration of CM in relation to the extract produced from the plant drug prepared at room temperature. By contrast, no significant difference was observed in the UMB content. Similarly, Rocha et al. (2008) showed that the tincture of Mikania glomerata ("guaco") formulated from the plant drug produced
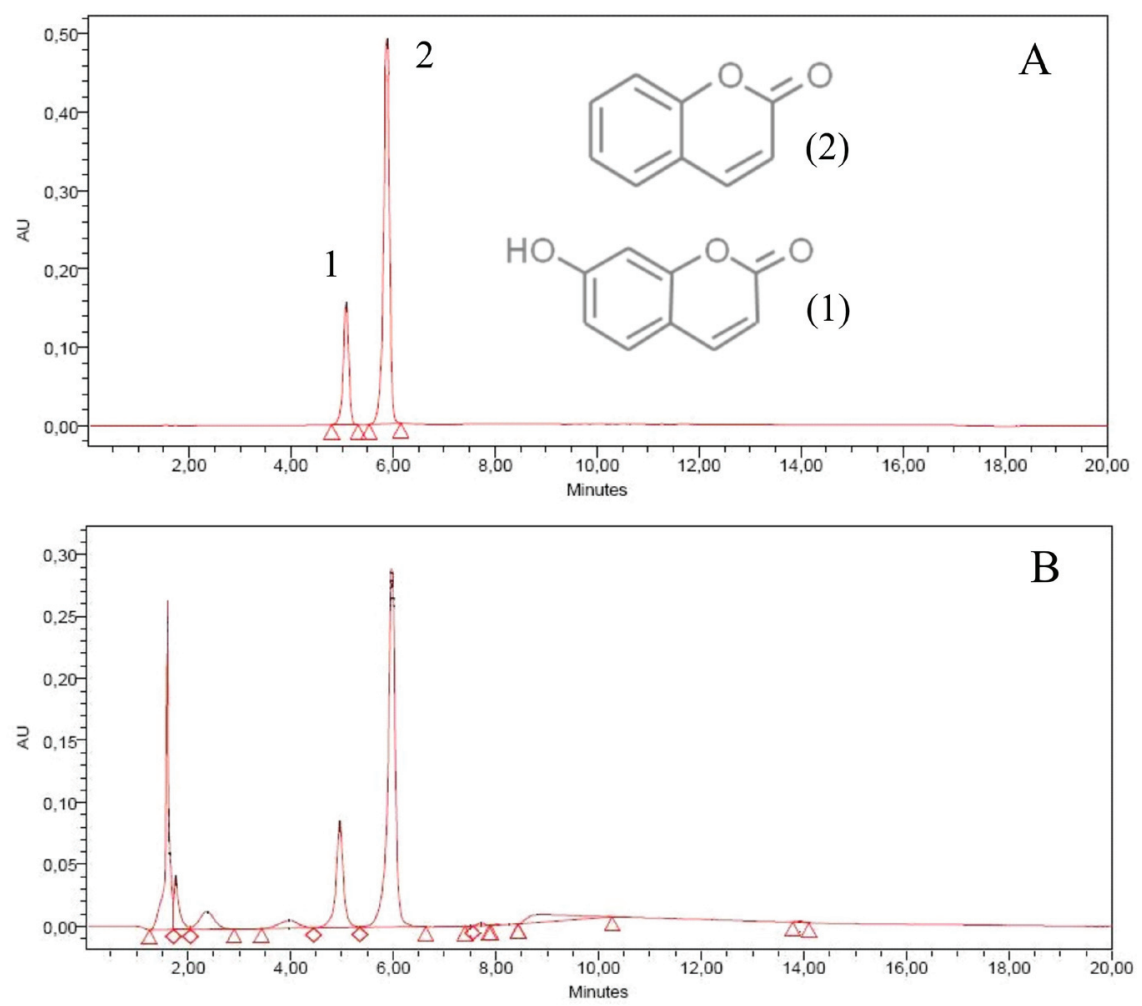

Figure 2. Chromatograms generated by the HPLC-PDA system for coumarin (CM) and umbelliferone (UMB) (A) and for the hydroethanolic extract of Justicia pectoralis (B). Conditions: C18 column, mobile phase (A, AcN:MeOH:THF; B, $\mathrm{H}_{2} \mathrm{PO}{ }_{4}: \mathrm{Et}_{3} \mathrm{~N}$, $\mathrm{pH} 3$ ), elution gradient, injection volume of $20 \mu \mathrm{L}$, flow rate $1.8 \mathrm{~mL} / \mathrm{min}$ and $\lambda=323 \mathrm{~nm}$. 
in an oven had a higher $\mathrm{CM}$ content in relation to that produced at room temperature; furthermore, Costa et al. (1998) noted a better visual quality in "guaco" leaves dried in an oven when compared to the leaves dried at room temperature. Given the evidence, the drying of "chambá" in an oven appears to have advantages related to the prevention of possible physical and chemical modifications of the plant (Figure 2).

The results obtained in the present study concerning the preparation and characterization of the plant drug produced from the aerial parts of $J$. pectoralis are highly relevant to the development of phytomedicines and can be recommended as safe parameters for the quality control of $J$. pectoralis, the active plant raw material with potential applications in the production of phytomedicines useful for the National Health Service.

\section{ACKNOWLEDGEMENTS}

The authors are grateful to the Fundação Cearense de Amparo à Pesquisa and the Conselho Nacional de Pesquisa for financial support. We also thank the Training Pharmacy at the Universidade Federal do Ceará and the Núcleo de Fitoterapia of the Health Secretariat of the State of Ceará for providing the research infra-structure.

\section{REFERENCES}

Allen LV, Popovich NG, Ansel HC 2007. Formas Farmacêuticas e Sistemas de Liberação de Fármacos. Porto Alegre: Artmed.

Angelova N, Kong HW, Heijden RVD, Yang SY, Choi YH, Wang M, Hankemeier T, Greef JVD, Xu G, Verpoorte R 2008. Recent methodology in the phytochemical analysis of Ginseng. Phytochem Anals 19:2-16.

Anvisa 2003. Resolução RE no 899 de 29 de maio de 2003. Guia para validação de métodos analíticos e bioanalíticos. Diário Oficial da União, Agência Nacional de Vigilância Sanitária. Brasília-DF.

Anvisa 2010. Resolução RDC nº 14 de 31 de março de 2010. Dispõe sobre o registro de fitoterápicos. Ministério da Saúde. Agência Nacional de Vigilância Sanitária. Diário Oficial da União, Brasília-DF.

Blank AF, Costa AG, Arrigoni-Blank MF, Cavalcanti SCH, Alves PB, Innecco R, Ehlert PAD, Sousa IF 2007. Influence of season, harvest time and drying on Java citronella (Cymbopogon winterianus Jowitt) volatile oil. Rev Bras Farmacogn 17: 557-564.

Clodius L, Piller NB 1978. Conservative therapy for postmastectomy lymphedema. Chir Plastica 4: 193-202.

Costa CC, Casali VWD, Macedo JAB 1998. Secagem, embalagem e qualidade da matéria prima de guaco (Mikania glomerata). In: Workshop de Plantas Medicinais de Botucatu, Botucatu, SP. p.35.

Evans, WC 1996. Pharmacognosy. 14 $4^{\text {th }}$ Ed. London: WB Saunders.

Farias MR 2007. Avaliação da qualidade de matérias-primas vegetais. In: Simões CMO, Schenkel EP, Gosmann G, Mello JCP, Mentz LA, Petrovick PR (org.) Farmacognosia da planta ao medicamento. 7ed. Porto Alegre: UFRGS,
Florianópolis: UFSC

Farmacopéia Brasileira 1988. IV ed. São Paulo: Editora Atheneu.

Farmacopéia Brasileira 2000. IV ed. São Paulo: Editora Atheneu.

Fonseca FN, Moura RR, Moura LMR, Viana GSB, Leal LKAM 2007. Development and validation of analytical method for Justicia pectoralis and its derivated product by HPLC. $6^{\text {th }}$ International Congress of Pharmaceutical Sciences. Ribeirão Preto, Brazil.

Fonseca FN 2009. Desenvolvimento tecnológico de fitoproduto a partir de Justicia pectoralis - chambá: obtenção do extrato seco padronizado (CLAE-DAD) e avaliação farmacológica. Dissertation, Master's degree in Pharmaceutical Sciences, 130 p. Universidade Federal do Ceará, Fortaleza.

Gaedcke F 2004. Mo“ glichkeiten der Entwicklung innovativer Phytopharmaka aus Sicht der Wirkstoff- (Extrakt-) Hersteller. Z Phytother 25: 31-40.

Govin LES, Hernandez FLL, Figueredo DC, Ferradá CAR 2003. Estudio farmacognóstico de Justicia pectoralis Jacq. var. stenophylla Leonard. Rev Cubana Plant Med 8. Available on http://scielo. sld.cu/scielo.php? script $=$ sci arttext\&pid $=$ S102847962003000300005\&lng=es\&nrm=iso. Access november 2010 .

Joseph H, Gleye J, Moulis C, Fouraste I, Stanislas E 1988. $O$-methoxylated $\mathrm{C}$-glycosylflavones from Justicia pectoralis. J Nat Prod 51: 804-805

Kroll U, Cordes C 2006. Pharmaceutical prerequisites for a multi-target therapy. Phytomedicine 13: 12-19.

Leal LKAM, Ferreira AAG, Bezerra GA, Matos FJA, Viana GSB 2000. Antinociceptive, anti-inflammatory and bronchodilator activities of Brazilian medicinal plants containing coumarin: a comparative study. $J$ Ethnopharmacol 70: 151-159.

Lino CS, Viana GSB, Matos FJA 1997. Analgesic and antiinflammatory activities of Justicia pectoralis Jacq and its main constituents: coumarin and umbelliferone. Phytother Res 11: 211-215

List PH, Schmidt PC 2000. Phytopharmaceutical Technology. Florida, CRS Press.

Matos FJA 2000. Plantas medicinais: guia de seleção e emprego de plantas usadas em fitoterapia no nordeste do Brasil. Fortaleza: Imprensa Universitária - UFC.

Ministério da Saúde 2008. Relação Nacional de Plantas Medicinais de interesse para o SUS. Available on http:// portal.saude.gov.br/portal/arquivos/pdf/RENISUS.pdf. Access on May 2009.

Nobre MEP, Leite GL, Barbosa MAC, Sousa LR, Sólon PCD, De Brito SPC, Viana GSB 2006. Avaliação da eficácia do xarope de chambá (Justicia pectoralis Jacq.) na função pulmonar de pacientes asmáticos. J Bras Fitomed 4: 4-10.

Oliveira AFM, Andrade LH 2000. Caracterização morfológica de Justicia pectoralis Jacq. e J. gendarussa Burm. F. (Acanthaceae). Acta Amazônica 30: 569-578.

Pereira EC, Lucetti DL, Barbosa-Filho JM, de Brito EM, Monteiro VS, Patrocínio MC, de Moura RR, Leal LK, Macedo DS, de Sousa FC, de Barros Viana GS, Vasconcelos SM 2009. Coumarin effects on amino acid levels in mice prefrontal cortex and hippocampus. Neurosci Lett 454: 139-142.

Prista LN, Alves AC, Morgado R 1996. Tecnologia Farmacêutica. 
$4^{\mathrm{a}}$ ed., Lisboa: Fundação Calouste Gulbenkian.

Ramesh B, Pugalendi KV 2005. Antihyperlipidemic and antidiabetic effects of umbelliferone in streptozotocin diabetic rats. Yale J Biol Med 78: 189-196.

Rocha L, Lucio EMA, França HS, Sharapin N 2008. Mikania glomerata Spreng: Desenvolvimento de um produto fitoterápico. Rev Bras Farmacogn 18: 744-747.

Sharapin N 2000. Fundamentos de tecnologia de produtos fitoterápicos. $1^{\mathrm{a}}$ Ed., Colômbia:CAB e CYTED.

Trueba GP, Martínez RR, Ruiz ZP, Chanfrau JR 2001. Evaluación de la actividad antioxidante de Justicia pectoralis Jacq. Rev Cubana Invest Biomed 20: 30-33.

Vasconcelos JF, Teixeira MM, Barbosa-Filho JM, Agra MF, Nunes XP, Giulietti AM, Ribeiro-Dos-Santos R, Soares MB 2009. Effects of umbelliferone in a murine model of allergic airway inflammation. Eur J Pharmacol 609: 126-131.

Venâncio ET, Rocha NFM, Rios ERV, Feitosa ML, Linhares MI, Melo FHC, Matias MS, Fonseca FN, Sousa FCF, Leal LKAM, Fonteles MMF 2010. Anxiolytic-like effects of standardized extract of Justicia pectoralis (SEJP) in mice: involvement of GABA/benzodiazepine in receptor 2010. Phytother Res DOI: 10.1002/ptr.3274 (accepted)

Wang Y-C, Yang Y-S 2007. Simultaneous quantification of flavonoids and triterpenoids in licorice using HPLC. $J$ Chromatogr B 850: 392-399.

World Health Organization 1998. Quality Control Methods for Medicinal Plant Materials. Geneva

World Health Organization 2005. Good Manufacturing Practices: updated supplementary guidelines for the manufacture of herbal medicinal.

Yamamoto C H, Pinto T J A, Meurer VM, Carvalho AM, Rezende P 2004. Controle de Qualidade Microbiológico de Produtos Farmacêuticos, Cosméticos e Fitoterápicos Produzidos na Zona da Mata, MG. In: Congresso Brasileiro de Extensão Universitária, Belo Horizonte. 